\title{
Analisis Data Curah Hujan Kabupaten Ketapang dan Kota Pontianak Menggunakan Transformasi Wavelet
}

\author{
Siti Hajrula ${ }^{a}$ Muliadia ${ }^{*}$, Riza Adriat ${ }^{b}$ \\ aProgram Studi Fisika FMIPA Universitas Tanjungpura, \\ b Program Studi Geofisika FMIPA Universitas Tanjungpura \\ Jalan Prof. Dr. Hadari Nawawi, Pontianak, Indonesia \\ *Email : muliadi@fmipa.untan.ac.id
}

\begin{abstract}
Abstrak
Data curah hujan di Kabupaten Ketapang dan Kota Pontianak dianalisis untuk mengetahui pola curah hujan di Kabupaten Ketapang dan Kota Pontianak. Data yang digunakan adalah data curah hujan bulanan selama 30 tahun (1986-2016), dengan menggunakan transformasi wavelet. Hasil penelitian ini menunjukkan bahwa metode tersebut dapat memperlihatkan pola curah hujan melalui Wavelet Power Spectrum (WPS) dan Global Wavelet Spectrum (GWS) disetiap stasiun pengamatan. Hasil dari WPS menunjukkan bahwa intensitas curah hujan yang tinggi di Kabupaten Ketapang adalah pada periode 1 tahun dan periode 3 tahun dengan pola hujan tahunan. Tingginya intensitas curah hujan dipengaruhi oleh fenomena El Niño Southern Oscillation (ENSO), yang merupakan hasil dari pengolahan data indeks ENSO dengan data curah hujan menggunakan cross wavelet. Di Kota Pontianak intensitas curah hujanyang tinggi terjadi pada periode 0,5 tahun dan periode 1 tahun dengan pola hujan musiman dan tahunan.
\end{abstract}

Kata kunci : Transformasi wavelet, Ketapang, Pontianak, dan curah hujan

\section{Latar Belakang}

Curah hujan merupakan salah satu unsur cuaca yang memiliki pengaruh sangat besar terhadap kegiatan manusia dan memiliki tingkat keragaman, baik secara waktu maupun secara tempat. Keadaan ini disebabkan posisi Kabupaten Ketapang dan Kota Pontianak yang dilalui garis khatulistiwa. Letak geografis Kabupaten Ketapang dan Kota Pontianak yang dilalui oleh garis khatulistiwa/ekuator menyebabkan beriklim tropis basah dengan suhu udara relatif panas disertai dengan kelembaban yang tinggi [1].

Selain iklim tropis, terdapat beberapa fenomena yang mempengaruhi kondisi curah hujan di Indonesia, antara lain fenomena El Niño Southern Oscillation (ENSO) dan Dipole Mode (DM). ENSO merupakan fenomena cuaca yang terjadi di wilayah Samudra Pasifik, sedangkan DM merupakan fenomena cuaca yang terjadi di wilayah Samudra Hindia. Secara umum peristiwa ENSO dan DM berulang antara 2 (dua) sampai 7 (tujuh) tahun [3]. Pengaruh fenomena ENSO dan DM terhadap curah Hujan di Kabupaten Ketapang, dengan transformasi wavelet memperlihatkan varian curah hujan yang tinggi di Kabupaten Ketapang bersesuaian dengan kejadian ENSO dan DM [2]. Transformasi wavelet merupakan pengembangan dari transformasi fourier yang dirancang untuk menganalisis sinyal non-stasioner yaitu sinyal dengan frekuensi yang berubah terhadap waktu [5]. Penelitian mengenai karakteristik osilasi curah hujan di Sumatra Barat berdasarkan transformasi wavelet didapatkan bahwa osilasi dominan yang mempengaruhi pola curah hujan Sumatra Barat adalah osilasi tahunan [4]. Mengenai perilaku curah hujan diKalimantan Barat (Pontianak, Ketapang, Putussibau, Sintang, dan Sambas), dengan penggunaan metode Power Spectral Density (PSD) menunjukkan bahwa curah hujan di wilayah Kalimantan Barat dipengaruhi oleh fenomena monsun. Angin yang mempengaruhi curah hujan di Ketapang adalah angin monsun dan di Pontianak dipengaruhi oleh fenomena DM[7].

Berdasarkan penelitian yang telah dilakukan sebelumnya oleh Elifant \& Ihwan (2014), pola curah hujan di Ketapang dan Pontianak penting untuk dikaji menggunakan metode transformasi wavelet. Hasil penelitian ini diharapkan dapat memperlihatkan pola curah hujan yang terjadi dalam rentang 30 tahun di stasiun Ketapang dan stasiun Pontianak. Keuntungan menggunakan metode transformasi wavelet adalah secara otomatis memisahkan tren dari data dan menunjukkan komponen musiman datanya dan 
menganalisis frekuensi dan waktu secara bersamaan.

\section{Metodologi}

Wilayah kajian dalam penelitian ini adalah Kabupaten Ketapang dan Kota Pontianak seperti ditunjukkan oleh Gambar 1.

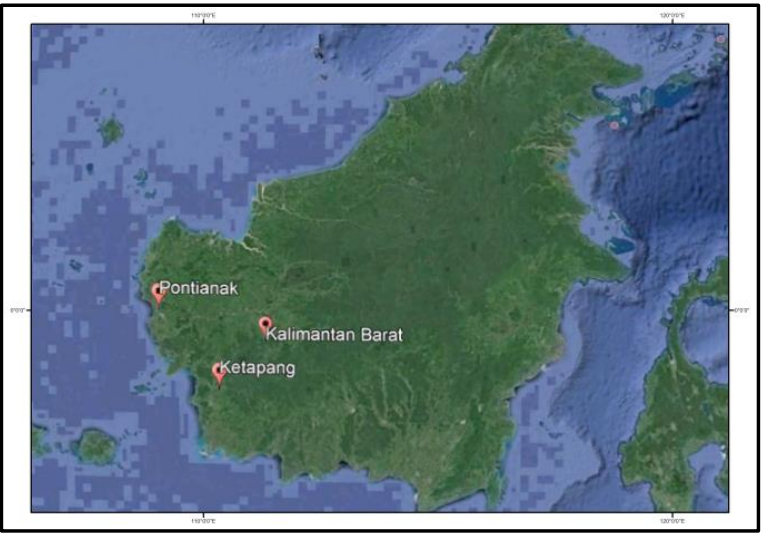

Gambar 1. Lokasi Penelitian

Dalam penelitian ini data yang digunakan adalah data curah hujan Kabupaten Ketapang dan Kota Pontianak. Data indeks ENSO dan data indeks DM diunduh dari situs web NOAA (National Oceanic and Atmospheric) ESRL (The Earth System Research Laboratory). Ketiga data tersebut berupa data bulanan selama 30 tahun dari bulan Januari 1986 - Desember 2016.

\subsection{Transformasi Wavelet}

Pada penelitian ini digunakan transformasi wavelet dengan persamaan Torrence dan Compo (1998) berdasarkan langkah-langkah sebagai berikut:

1. Untuk menentukan nilai dari transformasi wavelet digunakan persamaan:

$W_{n}(s)=\sum_{k=0}^{N=1} x_{k} \psi\left(s \omega_{k}\right) e^{i \omega_{k} n \delta t}$

dengan transformasi wavelet $W_{n}(s)$ merupakan konvolusi (perkalian bintang) dari fungsi wavelet dan deret waktu awal, $\omega_{k}= \pm(2 \pi k / N \delta t)$ merupakan frekuensi angular, $\delta t$ merupakan interval waktu, $s$ merupakan parameter dilatasi yang digunakan untuk merubah skala, $n$ merupakan parameter translasi yang digunakan untuk menggeser dalam sumbu waktu, $x_{k}$ merupakan deret waktu pada indeks waktu $k$, dan $k$ merupakan indeks frekuensi, dengan $\delta t=1 / 12$ selama 30 tahun. Jenis induk wavelet morlet $\left(\omega_{0}=6\right)$. Pada transformasi wavelet dikenal juga istilah faktor turunan empiris yang disebut COI (cone of influence), spektrum yang berada di luar batasnya adalah error yang terjadi dalam analisis time-series terbatas pada awal dan akhir wavelet-power spectrum. Untuk morlet, nilai COI nya adalah $C_{\delta}=0,776, \gamma=2,32, \delta_{j 0}=$ 0,60 dan $\psi_{0(0)}=\pi-1 / 4$. Dengan faktor rekontruksi $\left(C_{\delta}\right)$, faktor korelasi rata-rata waktu $(\gamma)$ dan faktor rata-rata skala $\left(\delta_{j 0}\right)$.

2. Luaran dari transformasi wavelet yang digunakan adalah spektrum wavelet yang dinyatakan oleh persamaan:

$$
S D=\left|W_{n}(S)\right|^{2}
$$

3. Luaran kedua adalah wavelet power spectrum yang dirata-ratakan untuk skala tertentu yang menggambarkan deret waktu varians $(\sigma)$ dalam skala waktu tertentu, diberikan oleh persamaan:

$$
\sigma^{2}=\frac{\delta j \delta t}{C_{\delta} N} \sum_{j-0}^{J} \frac{\left|W_{n}\left(s_{j}\right)\right|^{2}}{s_{j}}
$$

4. Luaran terakhir yang digunakan di dalam penelitian ini adalah spectrum global wavelet yang merupakan rata-rata daya wavelet atas semua spektrum lokal wavelet sepanjang sumbu waktu, diberikan oleh:

$$
W^{2}(S)=\frac{1}{N} \sum_{n=0}^{N-1}\left|W_{n}(S)\right|^{2}(4)
$$

\subsection{Cross Wavelet}

Data indeks ENSO dan data indeks DM $\left(X_{n}\right)$ dikorelasikan dengan data curah hujan $\left(Y_{n}\right)$ menggunakan metode kolerasi silang transformasi wavelet (cross wavelet transform atau $\mathrm{xwt}$ ) yang didefinisikan sebagai $W^{X Y}=W^{X} W^{Y *}$ dimana tanda $*$ adalah konjungsi kompleks (complex conjugation) dengan energi kolerasi silang transformasi wavelet sebesar $\left|W^{X} W^{Y}\right|$ pada selang kepercayaan 95\%. Kompleks argumen dari arg $\left(W^{X Y}\right)$ dapat menginterpretasi fase relatif lokal antara $X_{n}$ dan $Y_{n}$ di dalam domain frekuensi waktu. Distribusi energi kolerasi silang transformasi wavelet dengan background power spektral $P_{k}^{X}$ dan $P_{k}^{X Y}$ dan selang kepercayaan $Z_{v}$ (p) pada probabilitas $\mathrm{p}$, dihitung dengan persamaan 5 sebagai berikut (Torrence dan Compo, 1998) :

$$
D=\frac{\mid W_{n}^{X}(s) W_{n}^{Y}(s)}{\sigma X \sigma Y}<\mathrm{p}=\frac{z_{v}(p)}{v} \sqrt{\mathrm{P}_{\mathrm{k}}^{\mathrm{X}} \mathrm{P}_{\mathrm{k}}^{\mathrm{X}}}
$$

Dengan rata-rata sudut beda fase $a_{m}$ dari $a_{i}, \mathrm{i}=1 \ldots$ $\mathrm{n}$, dengan persamaan sebagai berikut:

$$
a_{m}=\arg (X, Y)
$$




$$
\begin{aligned}
& \text { dengan } X=\sum_{i=1}^{n} \cos a_{i} \\
& \operatorname{dan}_{Y=\sum_{i=1}^{n} \sin a_{i}}
\end{aligned}
$$

Adapun diagram alir pada penelitian ini dapat dilihat pada Gambar 2

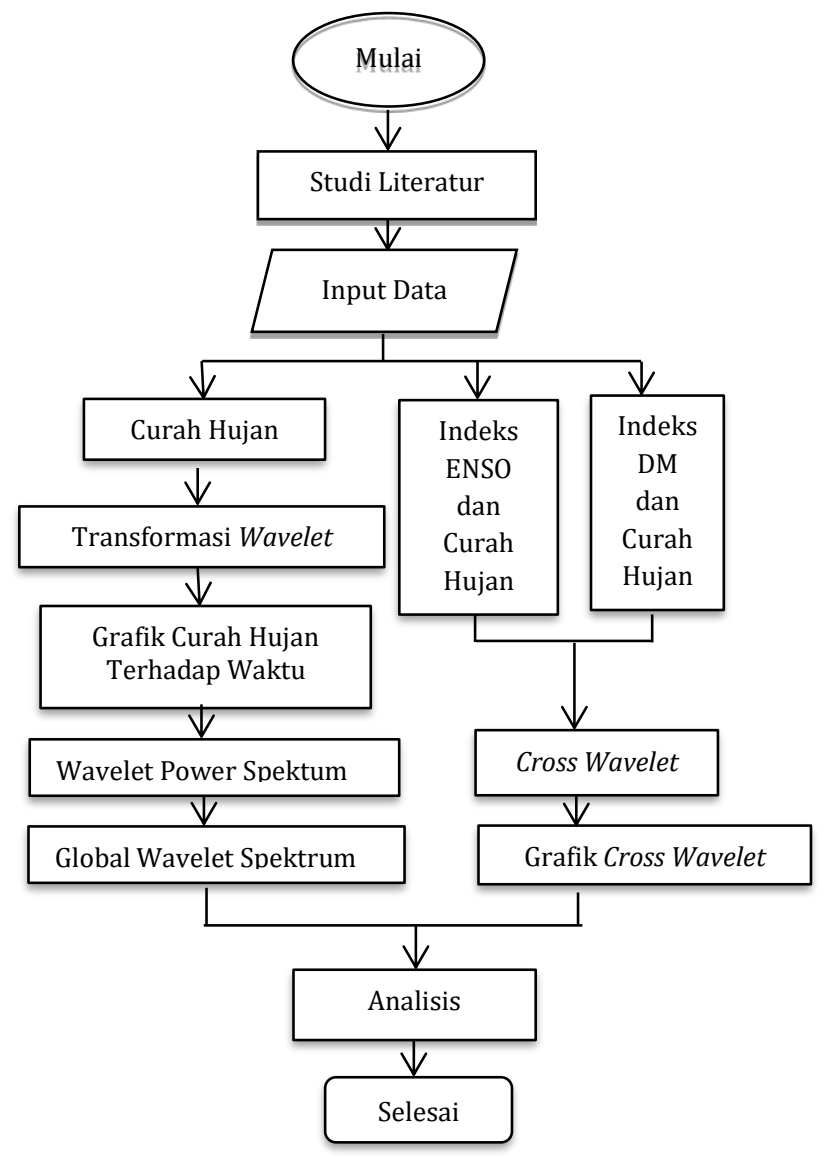

3. Hasil dan Pembahasan

3.1 Hasil Transformasi Wavelet dan Cross Wavelet Kabupaten Ketapang

Hasil pengolahan data curah hujan menggunakan metode transformasi wavelet menunjukkan intensitas curah hujan di stasiun Ketapang pada Gambar 3. Gambar 3(a) menunjukkan grafik curah hujan terhadap waktu selama 30 tahun. Gambar 3(b) wavelet power spectrum menunjukkan besarnya intensitas curah hujan yang telah dipecah menjadi beberapa periode, yang mana sumbu x merupakan waktu dan sumbu y menunjukkan periode. Warna merahyang paling gelap menunjukkan intensitas curah hujan yang tinggi dan warna putih menunjukkan data kosong selama periode data yang digunakan sebagai input. Gambar 3(c) global wavelet spectrum menunjukkan pola curah hujan dengan grafik paling ke kanan. Sumbu $x$ menunjukkan besarnya intensitas curah hujan dan sumbu y menunjukkan periode dari pola curah hujan.

Titik fokus yang dikaji dalam penelitian ini adalah ketika intensitas curah hujan berada pada titik ekstrim atau berada pada titik tertinggi. Respon tingginya intensitas curah hujan terhadap fenomena ENSO dan DM yang diberi tanda pada kolom warna putih pada gambar.

Gambar 2. Diagram alir penelitian

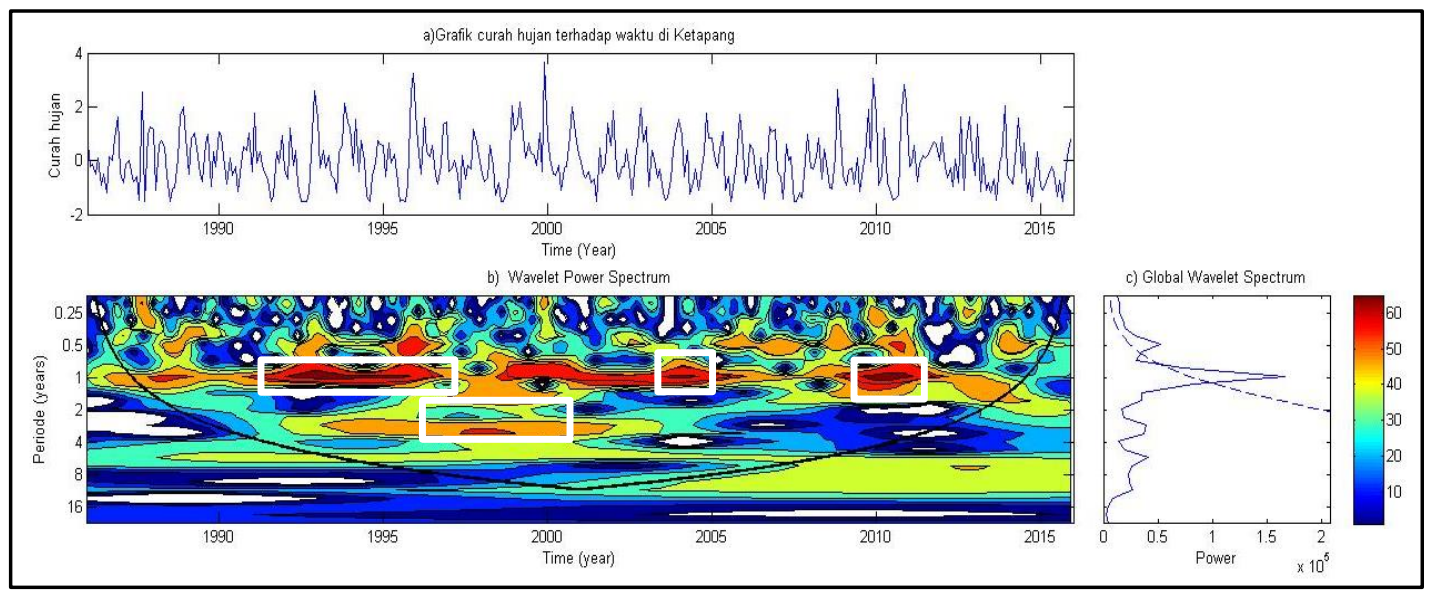

Gambar 3. (a) Grafik curah hujan terhadap waktu, (b) wavelet power spectrum dan (c) global wavelet spectrum di Kabupaten tahun (1986-2016) 


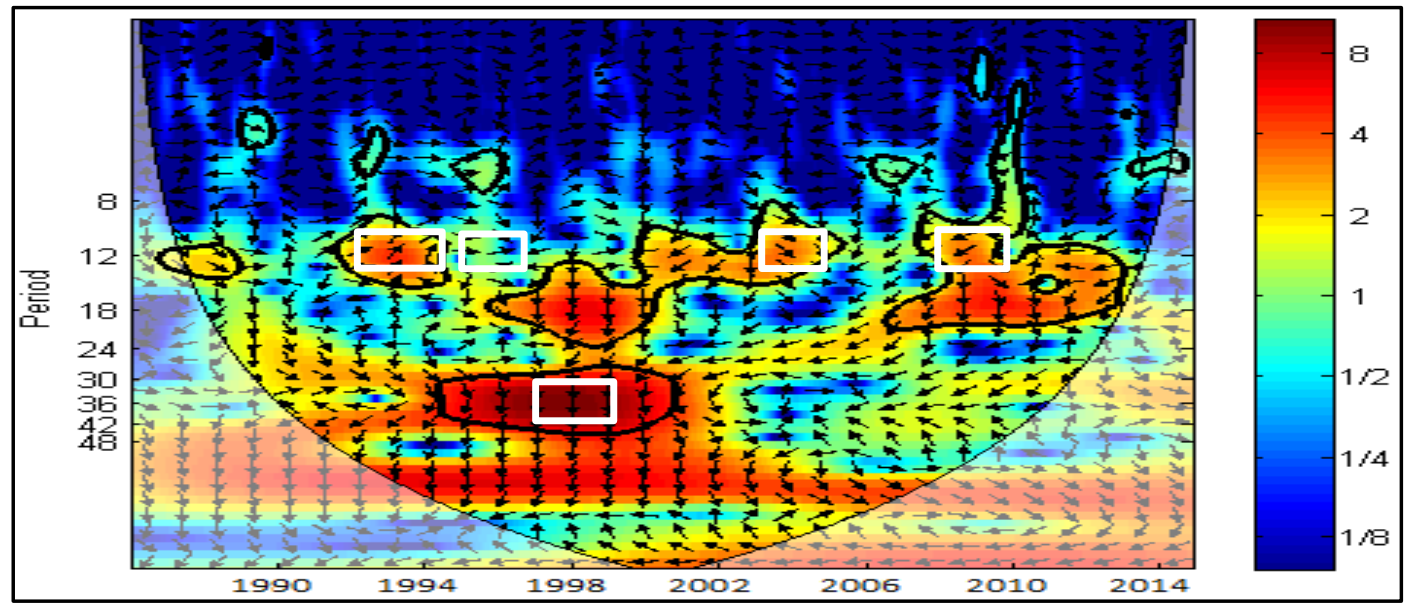

Gambar 4. Cross wavelet curah hujan dan indeks ENSO di Kabupaten Ketapang

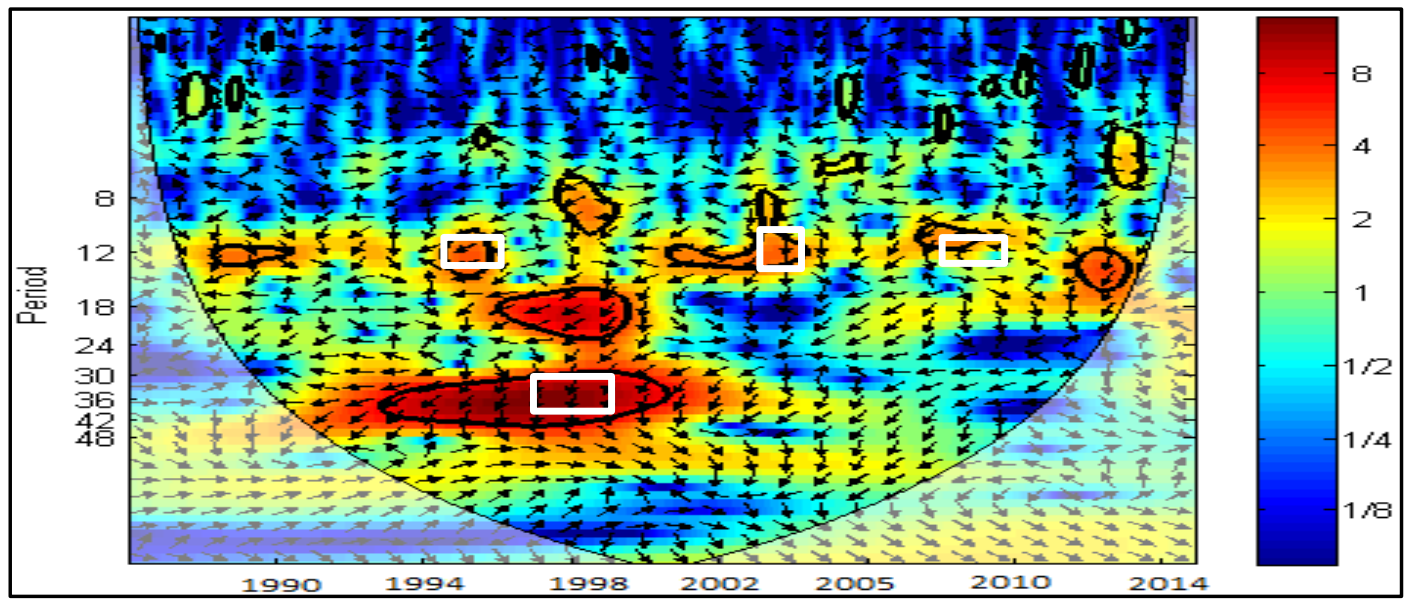

Gambar 5. Cross wavelet curah hujan dan indeks DM di Kabupaten Ketapang

Hasil pengolahan data curah hujan di Kabupaten Ketapang menggunakan metode wavelet pada wavelet power spectrum Gambar 3 (b), menunjukkan bahwa intensitas curah hujan yang tinggi terjadi pada periode 1 tahun dan periode 3 tahun. Pada periode 1 tahun intensitas curah hujan yang tinggi terjadi pada tahun 19921995, 2004, dan tahun 2009-2011. Pada periode 3 tahun intensitas curah hujan yang tinggi terjadi pada tahun 1998. Garis parabola di gambar menunjukkan error yang terjadi dalam analisis time-series terbatas pada awal dan akhir wavelet power spectrum.

Global wavelet spectrum digunakan untuk menggambarkan pola curah hujan di Kabupaten Ketapang. Grafik pada Gambar 3 (c) menunjukkan pola hujan terjadi pada periode 1 tahunan. Hal ini menunjukkan bahwa di Kabupaten Ketapang terjadi pola hujan tahunan. Garis putus-putus memotong grafik pada rentang periode terjadinya tingkat curah hujan tertinggi, hal ini berarti data yang diolah menunjukkan tingkat signifikan yang baik.

Hasil pengolahan data curah hujan dengan data indeks ENSO menggunakan metode cross wavelet pada Gambar 4, yaitu menunjukkan nilai korelasi antara parameter curah hujan dan indeks El Niño Southern Oscillation (ENSO). Korelasi tersebut memperlihatkan curah hujan terhadap fenomena ENSO. Intensitas curah hujan yang tinggi pada periode 1 tahun bertepatan dengan fase normal, terjadi pada tahun 1992-1993. Arah panah kekanan atas yang ditunjukkan pada Gambar 4 menunjukkan bahwa indeks ENSO lebih dahulu meningkat, selanjutnya disusul dengan tingginya curah hujan.

Intensitas curah hujan yang tinggi pada tahun 1994-1995 periode 1 tahun tidak dipengaruhi oleh fenomena ENSO. Hal ini terdapat pada Gambar 4 yang menunjukkan bahwa pada tahun 1994-1995 korelasinya rendah atau arah panah berada di luar kontur. Pada tahun 2004 intensitas curah hujan 
yang tinggi terjadi pada periode 1 tahun bertepatan dengan fase normal, arah panah kekanan bawah yang terdapat pada Gambar 4 menunjukkan bahwa curah hujan lebih dahulu meningkat, selanjutnya disusul dengan tingginya indeks ENSO. Tahun 2009-2011 terjadinya intensitas curah hujan yang tinggi bertepatan dengan fase La Niña lemah yang arah panahnya kekiri bawah dalam kolom warna putih pada Gambar 4 menunjukkan bahwa curah hujan lebih dahulu meningkat, selanjutnya disusul dengan tingginya indeks ENSO. Pada periode 3 tahun intensitas curah hujan yang tinggi bertepatan dengan fase La Niña lemah hingga La Niña moderat, terjadi pada tahun 1998. Arah panah kebawah yang terdapat pada Gambar 4 menunjukkan bahwa curah hujan lebih dahulu meningkat, selanjutnya disusul dengan tingginya indeks ENSO.

Hasil pengolahan data indeks DM dan curah hujan menggunakan metode cross wavelet ditunjukkan pada Gambar 5, yaitu menunjukkan nilai korelasi antara parameter curah hujan dan indeks Dipole Mode (DM). Korelasi tersebut menunjukkan fase curah hujan terhadap fenomena DM. Intensitas curah hujan yang tinggi terjadi pada tahun 2009-2011 periode 1 tahun, tidak dipengaruhi oleh fenomena DM. Hal ini dibuktikan pada Gambar 5 yang menunjukkan bahwa korelasi pada tahun 2009-2011berkorelasi rendah. Intensitas curah hujan yang tinggi pada tahun 1992-1995, bersamaan dengan terjadinya fenomena DM pada tahun 1995, sedangkan tahun 1992-1994 tidak bersamaan dengan terjadinya fenomena DM karena berkorelasi rendah atau berada di luar kontur yang ditunjukkan pada
Gambar 5. Intensitas curah hujan yang tinggi terjadi pada tahun 1995 bertepatan dengan fase normal. Arah panah kekiri bawah yang terdapat pada Gambar 5 menunjukkan bahwa curah hujan lebih dahulu meningkat, selanjutnya disusul dengan tingginya indeks DM. Pada tahun 2004 tinggi intensitas curah hujan yang terjadi pada periode 1 tahun, bertepatan dengan fase normal. Arah panah kebawah yang terdapat pada Gambar 5 yang menunjukkan bahwa curah hujan lebih dahulu meningkat, selanjutnya disusul dengan tingginya indeks DM. Intensitas curah hujan yang tinggi pada tahun 1998 periode 3 tahun bertepatan dengan fase DM normal. Hasil arah panah kekiri bawah dengan korelasi yang tinggi pada Gambar 5 menunjukkan bahwa curah hujan lebih dahulu meningkat, selanjutnya disusul dengan tingginya indeks DM.

Pengaruh fenomena ENSO dan DM terhadap curah hujan di Kabupaten Ketapang lebih kecil dibandingkan dengan pengaruh siklus angin monsun. Hal ini dikarenakan intensitas curah hujan di stasiun Ketapang bertepatan dengan fase normal, yang berarti bahwa iklim pada fase normal di Indonesia hanya dipengaruhi oleh fenomena monsun. Pengaruh fenomena ENSO terhadap tingginya intensitas curah hujan di stasiun Ketapang cenderung tinggi pada tahun 1998 periode 3 tahun.

\subsection{Hasil Transformasi Wavelet dan Cross Wavelet Kota Pontianak}

Hasil dari transformasi wavelet mengenai intensitas curah hujan di stasiun Pontianak ditunjukkan pada Gambar 6.

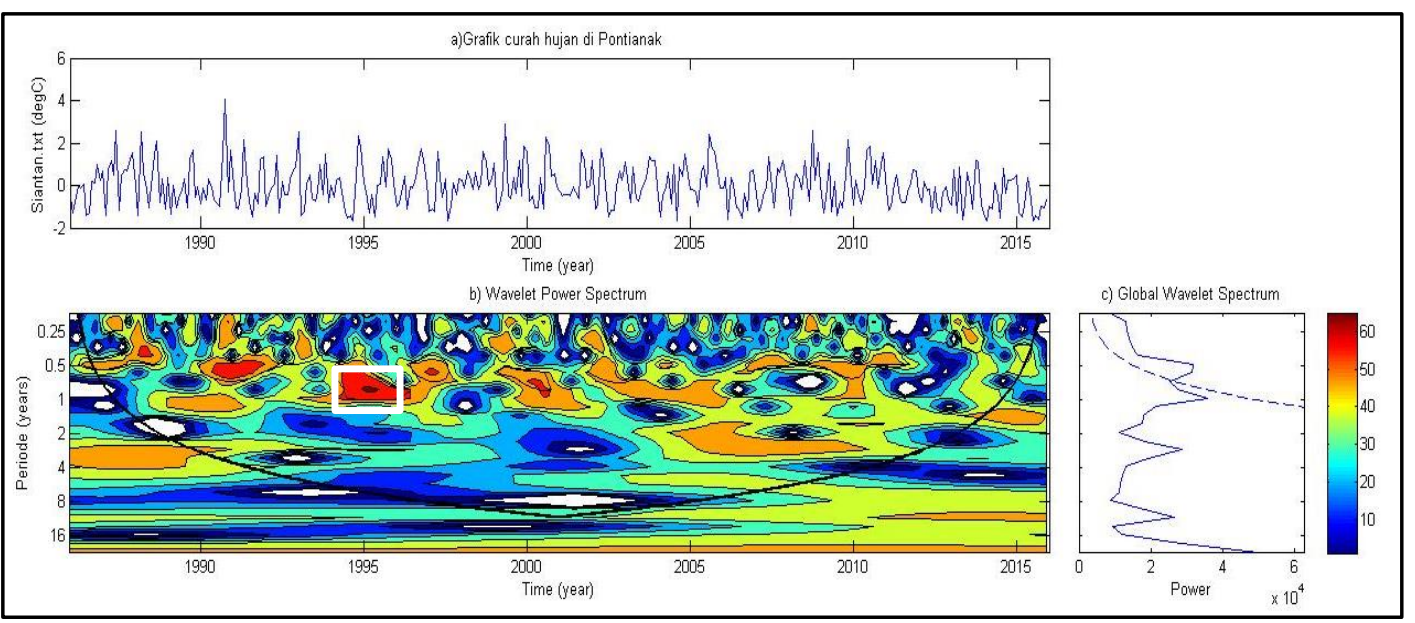

Gambar 6. (a) Grafik curah hujan terhadap waktu, (b) wavelet power spectrum, dan (c) global wavelet spectrum di Kota Pontianak tahun (1986-2016) 


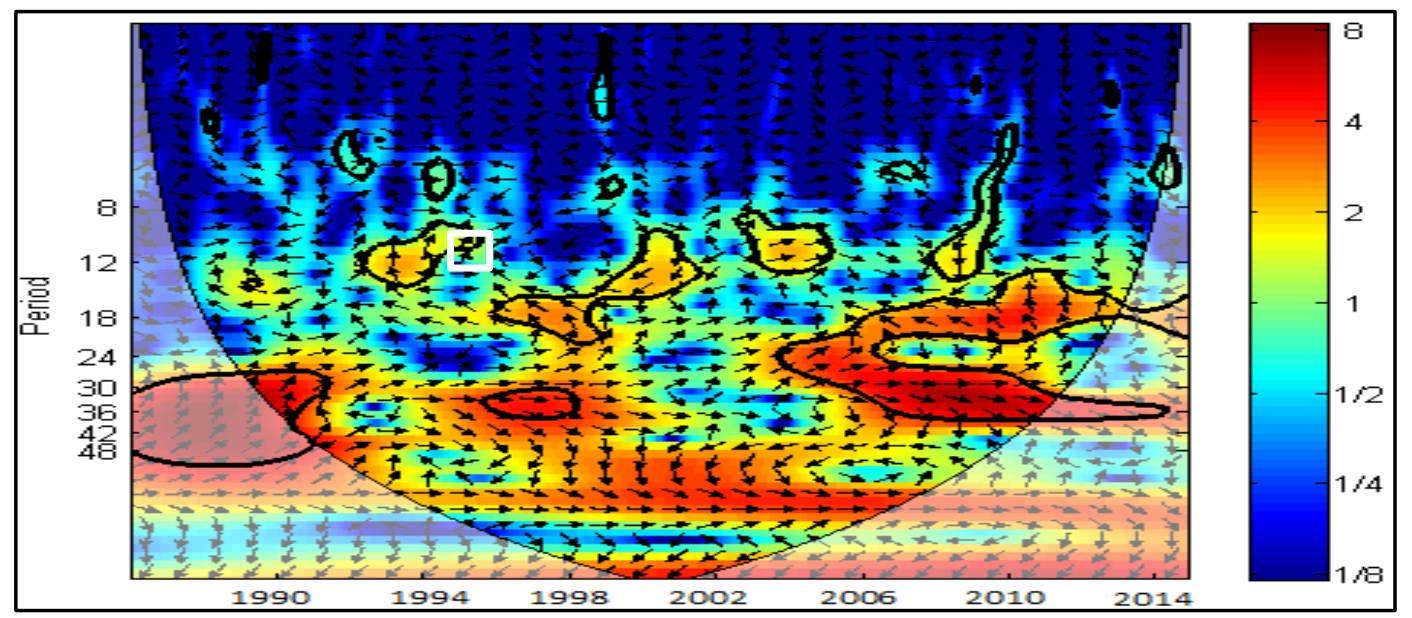

Gambar 7. Cross wavelet curah hujan dan indeks ENSO Kota Pontianak

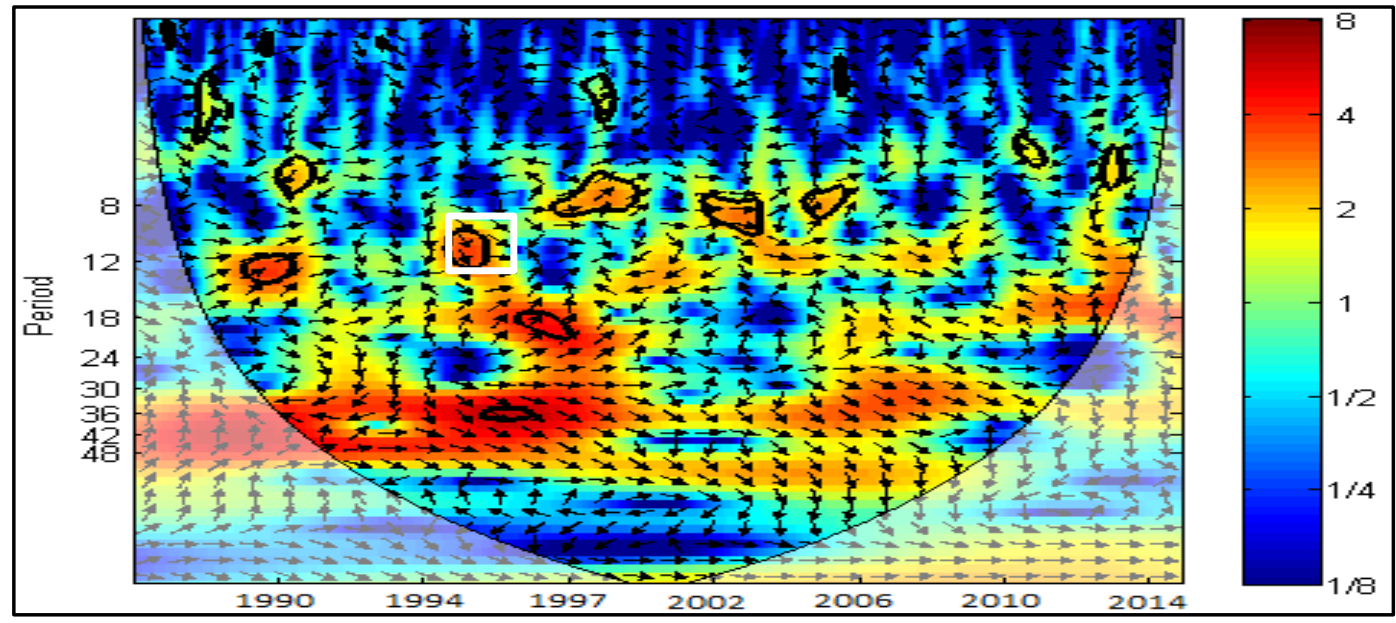

Gambar 8. Cross wavelet curah hujan dan indeks DM Kota Pontianak

Hasil pengolahan data curah hujan di Kota Pontianak menggunakan metode wavelet pada Gambar 6 (b), menunjukkan bahwa intensitas curah hujan yang tinggi terjadi pada tahun 1995 dengan rentang periode 0,5-1 tahun. Global wavelet spectrum digunakan untuk menggambarkan pola curah hujan di Kota Pontianak. Grafik pada Gambar 6 (c) menunjukkan pola hujan terjadi pada periode 0,5 tahun dan periode 1 tahun dan menunjukkan bahwa Kota Pontianak mengalami pola hujan setengah tahunan dan tahunan. Sama halnya dengan Gambar 3 (b), garis putus-putus memotong grafik pada rentang periode terjadinya tingkat curah hujan tertinggi, hal ini berarti data yang diolah menunjukkan tingkat signifikan yang baik.

Intensitas curah hujan yang tinggi pada tahun 1995 periode 0,5-1 tahun tidak dipengaruhi oleh fenomena ENSO. Hal ini dibuktikan dari hasil pengolahan data indeks ENSO dan curah hujan menggunakan metode cross wavelet pada Gambar 7 menunjukkan korelasi antara parameter curah hujan dan indeks El Niño Southern Oscillation (ENSO). Korelasi tersebut memperlihatkan bahwa intensitas curah hujan yang tinggi terhadap fenomena ENSO berkorelasi rendah.

Hasil pengolahan data indeks DM dan curah hujan, terdapat pada Gambar 8 menunjukkan korelasi antara parameter curah hujan dan indeks Dipole Mode (DM). Intensitas curah hujan yang tinggi pada periode 0,5-1 tahun tidak dipengaruhi oleh fenomena DM. Hal ini terdapat pada Gambar 8 yang menunjukkan bahwa korelasi pada tahun 1995 periode 0,5-1 tahun berkorelasi rendah atau arah panahnya berada di luar kontur. Intensitas curah hujan yang bersamaan dengan terjadinya fenomena DM yaitu pada periode 1 tahun, bertepatan dengan fase normal pada tahun 1995, dengan korelasi yang tinggi atau arah panahnya 
berada di dalam kontur. Arah panahnya kekanan bawah terdapat pada Gambar 8 yang menunjukkan bahwa curah hujan lebih dahulu meningkat, selanjutnya disusul dengan tingginya indeks DM.

Pengaruh fenomena ENSO dan DM terhadap curah hujan di Kota Pontianak lebih kecil dibandingkan dengan pengaruh siklus angin monsun. Hal ini dikarenakan intensitas curah hujan di Kota Pontianak bertepatan dengan fase normal, yang berarti bahwa iklim pada fase normal di Indonesia hanya dipengaruhi oleh fenomena monsun.

\section{Kesimpulan}

Berdasarkan hasil penelitian mengenai pola hujan Kota Pontianak dan kabupaten Ketapang menggunakan transformasi wavelet, dapat disimpulkan sebagai berikut.

1. Pola curah hujandi Kota Pontianak memiliki pola hujan musiman dan tahunan dengan periode 0,5 tahun dan periode 1 tahun pada tahun 1995.

2. Pola curah hujandi Kabupaten Ketapang memiliki pola hujan tahunan dengan periode 1 tahun, berlangsung pada tahun 1992-1995, 2004, dan tahun 2009-2011 dipengaruhi oleh fenomena El Niño Southern Oscillation (ENSO).

\section{Daftar Pustaka}

[1] BMKG., 2018. Buletin Cuaca Provinsi Kalimantan Barat. Badan Meteorlogi, Klimatologi dan Geofisika Stasiun Meteorlogi Kelas I Supadio Pontianak.

[2] Elifant, M.Y. \& Ihwan, A., 2014. "Pengaruh Fenomena El Niño Southern Oscillation dan Dipole Mode". POSITRON, vol IV, No 2(UNTAN Pontianak), pp.35-39.

[3] Hermawan, E. et al., 2010. "Pengembangan Ekspert Sistem Berbasis Indeks ENSO, DMI, Monsun, dan MJO Untuk Penentuan AwalMusim". Prosiding Pertemuan Ilmiah, XXIV HFI Jateng dan DIY, (Semarang), pp.1926.

[4] Laura, C., 2011. "A Wavelet Based Approach for Series Timing". PhD Thesis, (Polictechnica University of Timisoara and Telecom Bretagne, Timisoara).

[5] Rumahorbo, P. S. \& Marzuki., 2015. "Penggunaan Transformasi Wavelet untuk Menganalisis Osilasi Intramusiman Curah
Hujan di Kototabang". Jurnal Fisika Unand (Inpress).

[6] Torrence, C. dan Compo G. P., 1998. "A Pratical Guide to Wavelet Analysis". Bulletin of the American Meteorological Society, Vol. 79, No. 1, Hal. 61-78.

[7] Visa, J., Harjupa, W. \& Sunarsih, I.,2010. "Perilaku Curah Hujan Di Kalimantan Barat (Pontianak, Ketapang, Putussibau, Sintang, dan Sambas)". Prosiding Seminar Nasional Sains Atmosfer 2010, 16 Juni 2010, (Bandung) 